\title{
Which curve provides the best explanation of the growth in confirmed COVID-19 cases in Chile?*
}

\author{
Víctor Díaz-Narváez \\ (1) https://orcid.org/0000-0002-5486-0415 \\ David San-Martín-Roldán² \\ (iD) https://orcid.org/0000-0002-3208-8823 \\ Aracelis Calzadilla-Núñez ${ }^{3}$ \\ (D) https://orcid.org/0000-0002-6391-2563 \\ Pablo San-Martín-Roldán ${ }^{4}$ \\ (1D) https://orcid.org/0000-0002-3939-5818 \\ Alexander Parody-Muñoz ${ }^{5}$ \\ (D) https://orcid.org/0000-0003-0155-266X \\ Gonzalo Robledo-Veloso ${ }^{6}$ \\ (iD) https://orcid.org/0000-0002-6674-7823
}

Objective: to explore the best type of curve or trend model that could explain the epidemiological behavior of the infection by COVID-19 and derive the possible causes that contribute to explain the corresponding model and the health implications that can be inferred. Method: data were collected from the COVID-19 reports of the Department of Epidemiology, Ministry of Health, Chile. Curve adjustment studies were developed with the data in four different models: quadratic, exponential, simple exponential smoothing, and double exponential smoothing. The significance level used was $a \leq 0.05$. Results: the curve that best fits the evolution of the accumulated confirmed cases of COVID-19 in Chile is the doubly-smoothed exponential curve. Conclusion: the number of infected patients will continue to increase. Chile needs to remain vigilant and adjust the strategies around the prevention and control measures. The behavior of the population plays a fundamental role. We suggest not relaxing restrictions and further improving epidemiological surveillance. Emergency preparations are needed and more resource elements need to be added to the current health support. This prediction is provisional and depends on keeping all intervening variables constant. Any alteration will modify the prediction.

Descriptors: COVID-19; Coronavirus; 2019-nCoV; Coronavirus Infections; Pandemics; Epidemiology.

\section{How to cite this article}

Díaz-Narváez V, San-Martín-Roldán D, Calzadilla-Núñez A, San-Martín-Roldán P, Parody-Muñoz A, Robledo-Veloso $G$. Which curve provides the best explanation of the growth in confirmed COVID-19 cases in Chile?. Rev. Latino-Am. Enfermagem. 2020;28:e3346. [Access Available in: DOI: http://dx.doi.org/10.1590/1518-8345.4493.3346.

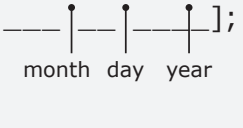




\section{Introduction}

The rising pneumonia called COVID-19, caused by SARS-CoV-2, exhibits strong infectivity but less virulence when compared to SARS-CoV-1 and MERS-CoV in terms of morbidity and mortality. It is not only a virus that spreads from one person to another, but probably spreads because many people become infected in various places through different mechanisms. Restricting the movement of people, reducing contact, disseminating key high-frequency prevention information through multiple channels, mobilizing state and local authorities to respond quickly to the contingency, can help contain the pandemic ${ }^{(1-5)}$.

The actual number of infected cases is much larger than that reported worldwide. The observed mortality rate of COVID-19 is estimated at around $4.8 \%$ worldwide. Although this rate is low in Chile, this estimate may be incorrect due to underestimation, because the likelihood that the health authorities will collect severe cases is higher and, as active cases increase, the health resources do not support the demand and overestimation, considering that the vast majority of cases without symptoms or with mild symptoms are not investigated(6-8).

The COVID-19 pandemicisan importantinternational test for the medical and scientific community, as it reveals weaknesses in the management of emerging viral diseases and reminds us that contagious diseases should never be underestimated. In addition, it has strained health systems due to the virulence and excess demand on hospitals ${ }^{(9-10)}$.

It is essential to understand the transmission dynamics of the infection, as it could determine whether outbreak control measures are exerting a significant effect. The numbers of newly infected cases largely depend on the effectiveness of the control measures. Several governments have rapidly incorporated recent scientific findings into public policies at community, regional and national levels to slow down and/or prevent the further spread of COVID-19. Control measures such as quarantine, travel restrictions and airport inspections for travellers have been widely implemented to contain the spread of infections. The effectiveness of these containment measures to control the outbreak is inconclusive though( ${ }^{(1,3,5-6,11)}$.

It is advisable for government entities to report on the current state of the pandemic in daily reports, specifying hospitalized and critical patients with COVID-19. Statistics need to be read carefully though, as it is leading to massive panic without organized solutions related to the redistribution of resources ${ }^{(12)}$.

Understanding the epidemiological characteristics of COVID-19 transmission in Chile is essential to formulate effective control strategies. The objective is to know what type of curve or model can best explain the epidemiological behavior of the accumulated confirmed cases of COVID-19 and identify the possible causes that contribute to explain the corresponding model and the health implications that can be inferred.

\section{Method}

Data were collected from the COVID-19 reports from the Department of Epidemiology of the Ministry of Health in Chile (MINSAL). The data are publicly available $^{(7)}$.

Curve adjustment studies were developed with the data in four different models: quadratic ${ }^{(13)}$, exponential(13-14), simple exponential smoothing using the formula $\left[F_{t}=F_{(t-1)}+a-A_{(t-1)}\right]$, where $F_{t}=$ new prognosis, $F_{(t-1)}=$ earlier prognosis and $A_{(t-1)}=$ actual value of the earlier prognosis and double exponential smoothing using Holt's method with trend adjustment $\left[\mathrm{FIT}_{\mathrm{t}}=\mathrm{F}_{\mathrm{t}}+\right.$ $\left.\mathrm{T}_{t}\right]$; where $\mathrm{FIT}_{t}$ is the forecasted value]; the components of this formula are: $\left[\mathrm{Ft}=\mathrm{F}_{(\mathrm{t}-1)}+\mathrm{a}\left(\mathrm{A}_{(\mathrm{t}-1)}-\mathrm{F}_{(\mathrm{t}-1)}\right)\right]$ $y\left[T_{t}=\delta\left(F_{t}-F_{(t-1)}\right)+(1-\delta) T_{t}^{(15-17)}\right.$. The following were estimated: the mean absolute percentage error (MAPE); the mean absolute deviation (MAD); the mean squared deviation (MSD). Criterion for choosing the best curve: small error coefficients. Indicator $a$ is the weighting used in the level component of the smoothened estimate and $\delta$ is the weighting used in the trend component of the smoothened estimate (similar to a moving average of the differences between consecutive observations)(15-16). To adjust the level of smoothing of the data (elimination of irregular fluctuations), the optimal ARIMA model was used for weighting, minimizing the sum of the square residues $^{(18-19)}$. The absolute error of each measure was the difference $(\Delta)$ between the actual observed value and the predicted value of confirmed cases for the same day. The median and interquartile range were estimated after checking for the normality of the absolute errors using the Kolmogorov-Smirnov test. Minitab $18.0^{\circledR}$ software was used. The significance level was $a \leq 0.05$.

\section{Results}

Figure 1 presents the estimated results of the regression equations of the observed data curves of confirmed, adjusted and predicted cases in the quadratic, exponential, simple exponential smoothing and double exponential smoothing models. The MAD, MAPE, and MSD coefficients are lower in the double exponential smoothing curve, which shows that the curve that best fits the evolution of the accumulated confirmed cases of COVID-19 in Chile is the one described above. 

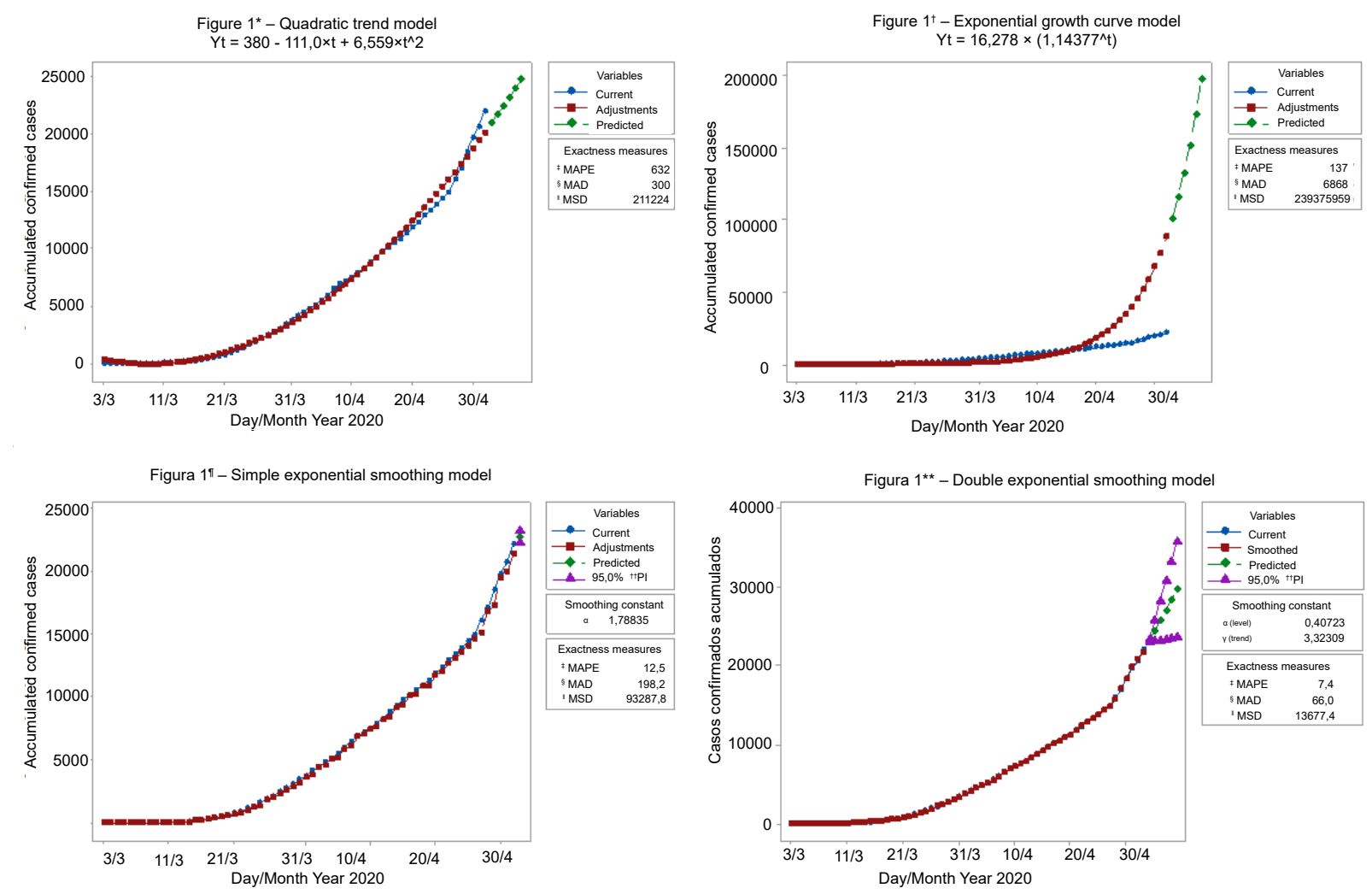

Figure $1^{*}=$ quadratic; Figure $1^{+}=$exponential; ${ }^{\ddagger}$ MAPE $=$ mean absolute percentage error; $\$$ MAD = mean absolute deviation; "MSD = mean squared deviation. Figure $1^{\mathbb{1}}=$ simple exponential smoothing; Figure $1^{* *}=$ double exponential smoothing $;{ }^{++}$IP $=$prediction interval

Figure 1 - Estimation results of the observed data curves of confirmed, adjusted and predicted cases, according to the model. Chile, 2020

Table 1 presents the results of estimating the predicted value on the previous day of confirmed cases (with its corresponding confidence interval) and the actual result of confirmed cases that occurred on the predicted day. The results of actual confirmed cases differ little from the predicted value $(S-W=0.907$; median $=53.2$ and interquartile range $=72.80$ ) and, with some exceptions, the actual value was within the estimated confidence interval for the predicted day.
Figure 2 and Table 2 present the estimation results of the forecasted number of confirmed cases from March $3^{\text {rd }}, 2020$ to August $30^{\text {th }}, 2020$. The MAPE coefficients are the lowest in the double exponential smoothing curve and the same is true for the MAD and MSD coefficients, which are low and acceptable. As observed, the confidence intervals increase as predicted further ahead and, therefore, the estimation error increases ${ }^{(18)}$.

Table 1 - Estimation results of the predicted value on the previous day of confirmed cases (with their corresponding confidence interval) and the actual result of confirmed cases that occurred on the predicted day, using the double exponential smoothing method. Chile, 2020

\begin{tabular}{ccc}
\hline Period & Prognosis $\left[{ }^{*} \mathbf{9 5 \%} \mathbf{C l}\right]$ & $\left(\mathbf{C C}^{+}\right)$ \\
\hline $03-23-2020$ & 763.25 & 746 \\
$03-24-2020$ & 883.53 & 1142 \\
$25-03-2020$ & 1053.34 & 1306 \\
$03-26-2020$ & $1360.68[1269.68 ; 1451.69]$ & 1610 \\
$03-27-2020$ & $1428.48[1338.48 ; 1518.48]$ & 1909 \\
$03-28-2020$ & $1823.25[1660.25 ; 1987.12]$ & 2139 \\
$03-29-2020$ & $2172.58[1985.46 ; 2359.70]$ & 2449 \\
$03-30-2020$ & $2421.80[2222.44 ; 2621.16]$ & 2738 \\
\end{tabular}


Table 1 - continuation

\begin{tabular}{|c|c|c|}
\hline Period & Prognosis $\left[{ }^{*} 95 \% \mathrm{Cl}\right]$ & $\left(\mathrm{CC}^{\dagger}\right)$ \\
\hline 04-01-2020 & $3026.17[2807.06 ; 3245.28]$ & 3031 \\
\hline 04-02-2020 & $3323.42[3097.77 ; 3549.07]$ & 3404 \\
\hline 04-03-2020 & $3713.18[3471.18 ; 3955.18]$ & 3737 \\
\hline 04-04-2020 & 4058.70 [3926.76 ; 4190.63] & 4161 \\
\hline 04-05-2020 & 4566.29 [4430.67; 4701.55] & 4471 \\
\hline 04-06-2020 & $4798.07[4659.68 ; 4936.46]$ & 4815 \\
\hline 04-07-2020 & $5162.60[5028.60 ; 5296.66]$ & 5116 \\
\hline 04-08-2020 & $5431.90[5298.90 ; 5564.91]$ & 5546 \\
\hline 04-09-2020 & $5934.95[5797.49 ; 6072.42]$ & 5972 \\
\hline 04-10-2020 & $6376.54[6240.11 ; 6512.67]$ & 6501 \\
\hline $04-11-2020$ & $6986.93[6844.31 ; 7129.54]$ & 6927 \\
\hline $04-12-2020$ & 7368.19 [7226.58; 7509.80$]$ & 7213 \\
\hline 04-13-2020 & $7554.50[7405.20 ; 7703.70]$ & 7525 \\
\hline 04-14-2020 & 7865.82 [7718.89; 8012.80] & 7917 \\
\hline $04-15-2020$ & 8297.20 [8151.20 ; 8443.10] & 8273 \\
\hline $04-16-2020$ & $8627.80[8484.48 ; 8771.10]$ & 8807 \\
\hline 04-17-2020 & $9281.20[9112.70 ; 9332.80]$ & 9252 \\
\hline 04-18-2020 & $9703.80[9608.90 ; 9798.70]$ & 9730 \\
\hline 04-19-2020 & $10198.50[10104.50 ; 10292.60]$ & 10088 \\
\hline 04-20-2020 & $10492.60[10394.90 ; 10590.20]$ & 10507 \\
\hline $04-21-2020$ & $10920.00[10823.90 ; 11016.40]$ & 10832 \\
\hline 04-22-2020 & $11193.90[11095.50 ; 11292.30]$ & 11296 \\
\hline 04-23-2020 & $11711.30[11610.90 ; 11812.40]$ & 11812 \\
\hline 04-24-2020 & $12283.70[12179.50 ; 12387.90]$ & 12306 \\
\hline 04-25-2020 & $12786.80[12686.50 ; 12893.00]$ & 12858 \\
\hline 04-26-2020 & $13384.20[13280.20 ; 13488.20]$ & 13331 \\
\hline $04-27-2020$ & $13826.10[13721.60 ; 13923.50]$ & 13813 \\
\hline 04-28-2020 & $14300.60[14197.40 ; 14403.80]$ & 14365 \\
\hline 04-29-2020 & $14888.50[14784.40 ; 14992.70]$ & 14885 \\
\hline 04-30-2020 & $15406.40[15303.90 ; 15508.90]$ & 16023 \\
\hline 05-01-2020 & $17006.90[16873.40 ; 17140.50]$ & 17008 \\
\hline 05-02-2020 & $18356.20[18224.90 ; 18487.60]$ & 18435 \\
\hline 05-03-2020 & $19885.00[19720.50 ; 19989.50]$ & 19663 \\
\hline 05-04-2020 & $20976.10[20837.80 ; 21114.40]$ & 20643 \\
\hline $05-05-2020$ & 21554.60 [21404.30; 21704.90] & 22016 \\
\hline
\end{tabular}

${ }^{*} \mathrm{CI}=$ Confidence interval; ${ }^{\dagger} \mathrm{CC}=$ Confirmed cases

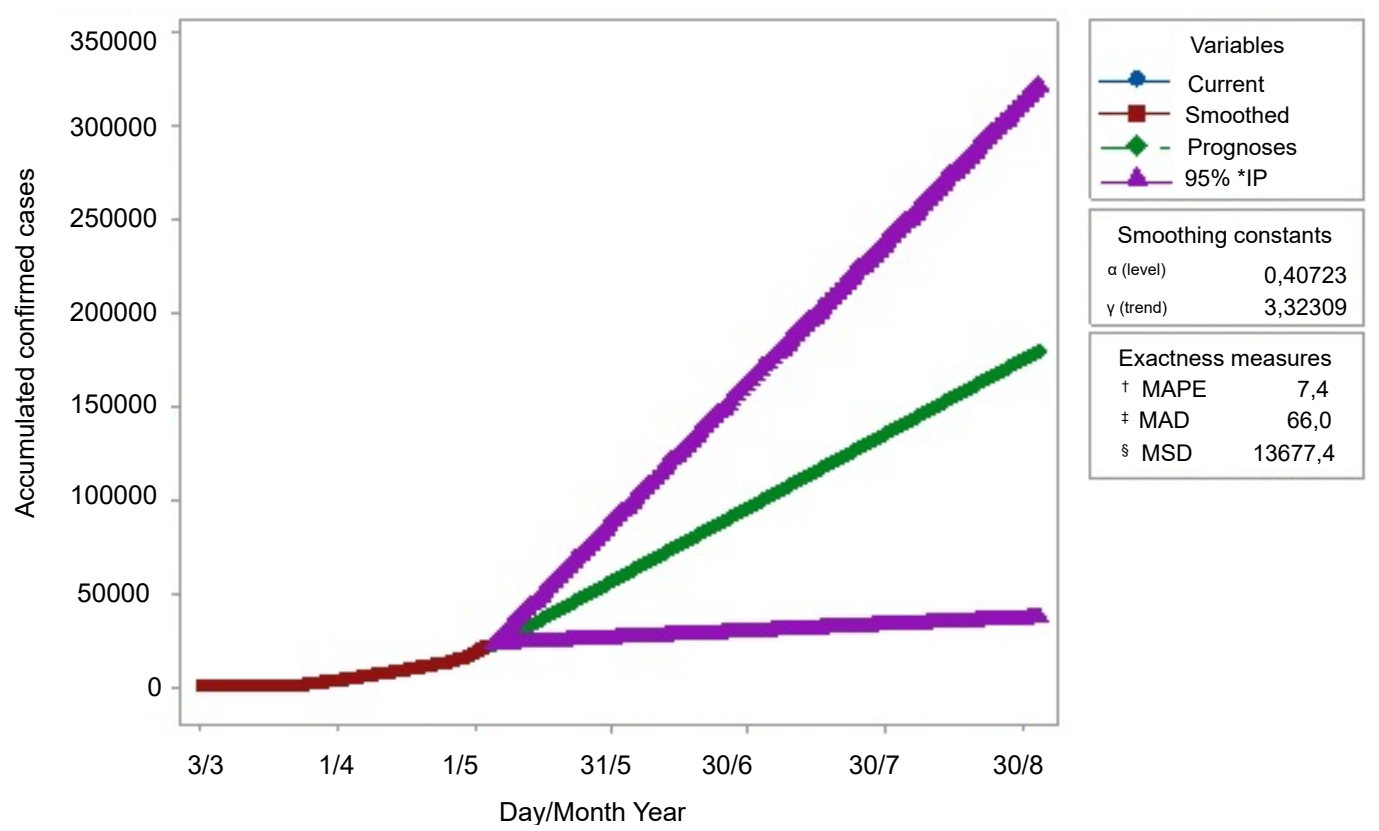

$*$ IP $=$ prediction interval $;{ }^{+}$MAPE $=$Mean absolute percentage error $;{ }^{*}$ MAD $=$ Mean absolute deviation; 5 MSD $=$ Mean squared deviation

Figure 2 - Estimation results of confirmed cases from the present until August 30 ${ }^{\text {th }}, 2020$ (Forecast). Chile, 2020 
Table 2 - Estimation results of confirmed cases from the present to August $30^{\text {th }}, 2020$, selected dates (forecasts) using the double exponential smoothing model. Chile, 2020

\begin{tabular}{|c|c|c|c|}
\hline Period & Forecast & $\mathrm{LL}^{*}-\mathrm{Cl}^{+}$ & $\mathrm{UL}^{\ddagger}-\mathrm{Cl}^{\dagger}$ \\
\hline 05-06-2020 & 23083 & 22921 & 23245 \\
\hline $05-07-2020$ & 24391 & 23074 & 25708 \\
\hline $05-08-2020$ & 25699 & 23193 & 28204 \\
\hline 05-09-2020 & 27006 & 23310 & 30703 \\
\hline $05-10-2020$ & 28314 & 23427 & 33201 \\
\hline $05-11-2020$ & 29622 & 23544 & 35700 \\
\hline $05-12-2020$ & 30930 & 23661 & 38199 \\
\hline $05-13-2020$ & 32238 & 23778 & 40698 \\
\hline $05-14-2020$ & 33546 & 23895 & 43197 \\
\hline $05-15-2020$ & 34854 & 24012 & 45696 \\
\hline $05-16-2020$ & 36162 & 24129 & 48195 \\
\hline $05-17-2020$ & 37469 & 24245 & 50693 \\
\hline $05-18-2020$ & 38777 & 24362 & 53192 \\
\hline $05-19-2020$ & 40085 & 24479 & 55691 \\
\hline $05-20-2020$ & 41393 & 24596 & 58190 \\
\hline $05-21-2020$ & 42701 & 24713 & 60689 \\
\hline $05-22-2020$ & 44009 & 24829 & 63188 \\
\hline $05-23-2020$ & 45317 & 24946 & 65687 \\
\hline $05-24-2020$ & 46625 & 25063 & 68186 \\
\hline $05-25-2020$ & 47932 & 25180 & 70685 \\
\hline $05-26-2020$ & 49240 & 25296 & 73184 \\
\hline $05-27-2020$ & 50548 & 25413 & 75683 \\
\hline $05-28-2020$ & 51856 & 25530 & 78182 \\
\hline $05-29-2020$ & 53164 & 25647 & 80681 \\
\hline $05-30-2020$ & 54472 & 25763 & 83180 \\
\hline $06-10-2020$ & 68858 & 27048 & 110669 \\
\hline $06-20-2020$ & 81937 & 28215 & 135659 \\
\hline $06-30-2020$ & 95016 & 29383 & 160649 \\
\hline $07-10-2020$ & 108094 & 30551 & 185638 \\
\hline $07-20-2020$ & 121173 & 31718 & 210628 \\
\hline $07-30-2020$ & 134252 & 32886 & 235618 \\
\hline 08-10-2020 & 148638 & 34170 & 263107 \\
\hline 08-20-2020 & 161717 & 35337 & 288097 \\
\hline $08-30-2020$ & 174796 & 36505 & 313087 \\
\hline
\end{tabular}

*LL: Lower limit; ${ }^{+}$CI: Confidence interval; ${ }^{\text {}}$ UL: Upper limit

\section{Discussion}

The progress of the COVID-19 pandemic in Chile fits well into a model and we study its predictive capacity. By analyzing the epidemiological characteristics and transmission dynamics of an emerging infectious disease, the key to successful outbreak control is obtained through mitigation strategies ${ }^{(6)}$.

The World Health Organization (WHO) has indicated that easing restrictions does not end the epidemic in any country. Ending the epidemic will require a sustained effort by individuals, communities and governments to continue to fight and control the virus. Active surveillance is recommended to detect cases early and isolate them, quickly locate those who have been in contact with the cases and monitor them so that patients can quickly access clinical care. If none of these points are achieved, any action or indication will be ineffective in containing the pandemic. Chile has disseminated neither the notified contact indicators nor the indicator of test results delivered within 24 hours. Contacts are being notified, but without any specification of the time. There are no statistics either with regard to compliance with quarantines or supervised discharge of confirmed patients $^{(1,7,20-21)}$.

WHO has provided support for epidemiological studies of seroprevalence, which suggest that the percentage of the population infected with antibodies may be relatively small (2-3\%), without knowing how long this immunity lasts ${ }^{(20)}$. 
The mathematical model of any process tries to describe its basic components and tries to predict some general trends, but it will never be able to provide an exact description and prediction(22). Various causes impede this in an epidemiological context: (a) no model can include all variables that influence a process; (b) there are unknown variables that cannot be incorporated in the prediction; (c) these variables depend on conditions and the specific nature of the virus, on the social conditions people live in, and on the immunity status of a particular patient; (d) the socio-economic infrastructure of a country; (e) the capacities of the health system at a given time, f) a smart health policy that a country could implement to prevent the spread and take the most appropriate measures to mitigate the impact of the process associated to these infections to the maximum; and $(\mathrm{g})$ on the intelligence and level of scientific knowledge of the authorities at all levels; ( $h$ ) the authorities' ability to learn from experiences observed in other parts of the world. The knowledge of these variables and the consequent intentional modification of all or some of these variables will modify the contagion rate in a positive or negative way. Therefore, this rate and the specific derivations of the nature of all of these variables make it impossible to create an exact forecast of the future. Thus, the model presented here can only provide a basis for a comprehension mechanism, under the type of circumstances, constraints and current population conditions. All of these aspects limit the predictive capacity and attention needs to be paid to changes in the determining factors that may constitute the cause compelling to change the model to explain the behavior of the pandemic. One of the transcendental aspects in epidemiology is to try to predict the evolution of infectious diseases. This attempt is usually done through models that consider the progress of cases over time in a certain place, transmissibility, among other causes. Nevertheless, these do not include the specific characteristics of the affected population (23-25).

The experience of European countries that have indicated specific population intervention measures has shown that the deceleration of the incidence is achieved when a percentage or critical mass of confirmed cases is reached, compared to the general population. That is the case for: Austria $(0.12 \%)$, Norway $(0.12 \%)$, Netherlands $(0.13 \%)$, Germany $(0.14 \%)$, France $(0.15 \%)$, Denmark $(0.15 \%)$, Switzerland $(0.17 \%)$, United Kingdom $(0.18 \%)$, Portugal $(0.18 \%)$, Iceland $(0.18 \%)$, Sweden $(0.20 \%)$, Spain $(0.21 \%)$ and Italy $(0.21 \%)$. It is estimated that the slowdown in the incidence in Chile would be achieved when the average of 31.527 ( $S D=12.160)$ confirmed cases is reached. That happens on May $13^{\text {th }}, 2020$ (May $10^{\text {th }}$ and July $\left.19^{\text {th }}\right)$. It should be mentioned that active cases in Chile represent $47.04 \%(S D=1.96)$ of confirmed cases, as of May $5^{\text {th }}, 2020$. The propensity of this percentage should tend to decrease gradually and slowly according to international experience, but it has stagnated for 13 days between $45-50 \%$. This stagnation is probably due to the fact that the public health strategies and the population's behavior are not equivalent to that of the countries mentioned(26-38).

Chile needs to remain vigilant and adjust strategies around prevention and control measures, which means to improve health actions and to strengthen surveillance systems and public health infrastructure to provide the early detection and rapid response. We hope, for the sake of Chilean health, that the support of infrastructure and health assets achieve the results in terms of effectiveness and do not pose a problem of needs and resources. At the same time, emergency preparations are necessary in response to a more serious outbreak that may occur ${ }^{(1,6)}$.

The monitoring of simple but at the same time critical parameters of patient behavior at an intensive care unit (ICU) grants us critical information to know these parameters and their evolution in terms of severity, providing information for the sake of control, intervention and mitigation strategy proposals. The current use of the intensive care capacity for COVID-19 patients represents on average $17.10 \%(S D=1.35)$ of the total available ICU beds in Chile. Whether the country reaches 20,111 active cases $(42,751$ confirmed cases, according to the active case/confirmed case ratio), the number of intensive care beds will not be sufficient for COVID-19 patients and this health support would collapse. This would happen on May $22^{\text {nd }}, 2020$. This calculation considers the current number of intensive care beds available in Chile: 3,264 and the average percentage of intensive care capacity use for COVID-19 patients in Chile, which is $8.28 \%(S D=1.06)$, and intensive care capacity use in non-COVID-19 patients, which is $48.96 \%(S D=1.74)$ (39-41). If the number of ICU beds remains constant and the incidence does not decelerate (as it falls within the error margin of the prediction), but the ratio of active cases/confirmed cases decreases, then the scenario of ICU collapse is likely.

Ventilation support is the cornerstone of the management of subjects with respiratory failure due to COVID-19. The current use of invasive mechanical ventilation (IMV) for COVID-19 patients represents on average $18.48 \%(S D=1.22)$ of the total mechanical ventilators (MV) available in Chile. If the country reaches 28,423 active cases $(60,418$ confirmed cases, according to the active case/confirmed case ratio), MV will not be sufficient for the ventilatory needs of COVID-19 patients 
and this health support would collapse. This would happen on June $4^{\text {th }}, 2020$. This calculation considers the current number of MV available in Chile: 1,825 and the average percentages in Chile of IMV use in COVID-19 patients, which is $5.01 \%$ ( $S D=0.67)$, and of IMV use in non-COVID-19 patients, which is $21.91 \%$ ( $S D=1.17$ ) (41-42). If the number of MV remains constant and the incidence rate (as it falls within the error margin of the prediction) and the active case/confirmed case ratio do not decrease, the scenario of health failure due to the lack of MV is plausible, although less likely than the collapse of the intensive care system.

This predictive model is provisional and depends on the constant use of all the variables maintained. Any change will undoubtedly modify the prediction and, therefore, daily variations should be monitored, although the predictive model does not present considerable and important faults in the current reality. The predictions of this model have been good and have a safety coefficient that allows us to calculate with some slack the public health needs the care for the current cases might require. This information is relevant when deciding on measures to contain an epidemic. The appropriate fit and good predictive capacity of this model makes it possible to propose it as an epidemiological method for monitoring and predicting the progression of infectious diseases in the local situation, e.g. regions, provinces and communes ${ }^{(43)}$.

Our approach has limitations. This study was based on the cases reported by MINSAL and contains the biases of case confirmation and information, which may be delayed with respect to the occurrence of cases, the delay in the appearance of symptoms due to the incubation period and the high proportion of unreported cases as a result of limited detection and testing capacity. Moreover, data sources may be biased, incomplete or only capture certain aspects, versus others that may be equally relevant, such as chronic pathologies, risk factors, nutritional status, among others.

This analysis does not necessarily represent the actual situation of the cases, as it excludes confirmed cases in laboratories not considered by surveillance systems and sub-clinical cases. This model does not consider variations due to seasonal changes, social aggregation, etc. either. In addition, it is dependent on the addition of new MV to the health network. This analysis of epidemiological characteristics provides important information on the behavior of COVID-19 to propose effective control strategies at all levels of health care(7).

\section{Conclusion}

The type of curve that best explains the behavior of COVID-19 in Chile is a doubly smoothed exponential curve. From this model, it follows that the number of infected cases will continue to increase. The number of confirmed cases will grow stronger and within a short time if the population behavior and public health measures are not in line with the size of this international public health emergency. We hope that the results will enable the medical staff and leaders to make decisions. In no case should restrictions be relaxed and epidemiological surveillance needs improvements, as this is not the end of the pandemic.

\section{References}

1. Epidemiology Working Group for NCIP Epidemic Response, Chinese Center for Disease Control and Prevention. The epidemiological characteristics of an outbreak of 2019 novel coronavirus diseases (COVID-19) in China. Zhonghua Liu Xing Bing Xue Za Zhi. 2020 Feb;41(2):145-51. doi: 10.3760/cma.j.is sn.0254-6450.2020.02.003

2. Guo YR, Cao QD, Hong ZS, Tan YY, Chen SD, Jin HJ, et al. The origin, transmission and clinical therapies on coronavirus disease 2019 (COVID-19) outbreak - an update on the status. Mil Med Res. 2020 Mar;7(1):11. doi: 10.1186/s40779-020-00240-0

3. Adhikari SP, Meng S, Wu YJ, Mao YP, Ye RX, Wang QZ, et al. Epidemiology, causes, clinical manifestation and diagnosis, prevention and control of coronavirus disease (COVID-19) during the early outbreak period: a scoping review. Infect Dis Poverty. 2020 Mar 17;9(1):29. doi: 10.1186/s40249-020-00646-x

4. World Health Organization. Novel Coronavirus-Japan (ex-China). [Internet] Geneva: WWHO; 2020 [cited Feb 1, 2020]. Available from: https://www.who.int/csr/don/17january-2020-novel-coronavirus-japan-ex-china/en/

5. Rothan HA, Byrareddy SN. The epidemiology and pathogenesis of coronavirus disease (COVID-19) outbreak. J Autoimmun. 2020 Feb:102433. doi: 10.1016/j.jaut.2020.102433

6. Park M, Cook AR, Lim JT, Sun Y, Dickens BL. A Systematic Review of COVID-19 Epidemiology Based on Current Evidence. J Clin Med. 2020 Mar;9(4). pii: E967. doi: $10.3390 / \mathrm{jcm} 9040967$

7. Departamento de Epidemiología. Ministerio de Salud (Chile). Situación Epidemiológica COVID-19. [Internet]. 2020 [Acceso 1 feb 2020]. Disponible en: http://epi. minsal.cl/wp-content/uploads/2020/04/Informe_27_ COVID_19_Chile.pdf

8. World Health Organization. COVID-19 Dashboard. [Internet]. 2020 [cited Apr 22, 2020]. Available from: https://who.sprinklr.com/

9. Kolifarhood G, Aghaali M, Mozafar Saadati H, Taherpour N, Rahimi S, Izadi N, et al. Epidemiological 
and Clinical Aspects of COVID-19; a Narrative Review. Arch Acad Emerg Med. [Internet]. 2020 Apr [cited Apr 22, 2020];8(1):e41. Available from: https://www.ncbi. nlm.nih.gov/pmc/articles/PMC7117787/pdf/aaem8-e41.pdf

10. World Health Organization. Coronavirus disease (COVID-19) Pandemic. [Internet]. Geneva: WHO; 2020 [cited Apr 28, 2020]. Available from: https://www.who. int/emergencies/diseases/novel-coronavirus-2019

11. Kucharski AJ, Russell TW, Diamond C, Liu Y, Edmunds J, Funk S, et al. Early dynamics of transmission and control of COVID-19: a mathematical modelling study. Lancet Infect Dis 2020; doi:10.1016/S14733099(20)30144-4

12. McCullough PA, Eidt J, Rangaswami J, Lerma E, Tumlin J, Wheelan $\mathrm{K}$, et al. Urgent need for individual mobile phone and institutional reporting of at home, hospitalized, and intensive care unit cases of SARSCoV-2 (COVID-19) infection. Rev Cardiovasc Med. 2020 Mar;21(1):1-7. doi: 10.31083/j.rcm.2020.01.42

13. Canavos GC. Probabilidad y Estadística. Aplicaciones y Métodos. Madrid: McGraw-Hill; 1988. Capítulo 14, p.538-47.

14. Piskunov N. Cálculo Diferencial e Integral. 2.ed. Moscú: Editorial MIR; 1977. pp. 253-67.

15. Mauricio JA. Introducción al Análisis de Series Temporales. Madrid: Universidad Complutense de Madrid; 2007 [Acceso 22 abr 2020]. pp. 125-137. Disponible en: https://www.ucm.es/data/cont/ docs/518-2013-11-11-JAM-IAST-Libro.pdf

16. Taylor JK, Cihon C. Statistical Techniques for Data Analysis. 2.ed. Miami: Chapman \& Hall/CRC; 2004. p. 174-99.

17. Holt CC. Forecasting Seasonals and Trends by Exponentially Weighted Moving Averages. Pittsburgh, Carnegie Institute of Technology; 1957.

18. Villarreal F. Introducción a los modelos de pronósticos. [Internet] Bahia Blanca: Universidad Nacional del Sur; 2016 [Acceso 1 feb 2020]. Disponible en: https://www.matematica.uns.edu.ar/ uma2016/material/Introduccion_a_los_Modelos_de_ Pronosticos.pdf

19. Jiménez JF, Gázquez JC, Sánchez R. la capacidad predictiva en los métodos de Box-Jenkins y HoltWinters: una aplicación al sector turística. Rev. Eur. Dir. Econ. Empres. [Internet]. 2006 [Acceso 1 feb 2020];15(3):185-219, Disponible en: https://dialnet. unirioja.es/descarga/articulo/2150087.pdf

20. World Health Organization. Director-General's opening remarks at the media briefing on COVID-19 - 20 April 2020. [Internet]. Geneva: WHO; 2020 [cited Apr 22, 2020]. Available from: https://www.who.int/ es/dg/speeches/detail/who-director-general-s-opening- remarks-at-the-media-briefing-on-covid-19---20april-2020

21. World Health Organization. Updated WHO recommendations for international traffic in relation to COVID-19 outbreak. [Internet]. Geneva: WHO; 2020 [cited Apr 22, 2020]. Available from: https://www. who.int/ith/2019-nCoV_advice_for_international_ traffic-rev/es/

22. Díaz V, Calzadilla A, López H. 2005. Una aproximación al concepto de Hecho Científico Cinta Moebio. [Internet]. 2005 [Acceso 1 feb 2020];22:100-11, Disponible en: www.moebio.uchile.cl/22/diaz.html

23. Moarefian M, Pascal JA, Fundamental mathematical model shows that applied electrical field enhances chemotherapy delivery to tumors. Math Biosci. 2016;272:1-5. doi: http://dx.doi.org/10.1016/j. mbs.2015.11.003

24. Salim F, Ioannidis M, Górecki T. Experimentally validated mathematical model of analyte uptake by permeation passive samplers. Environ Sci Process Impacts. 2017 Nov;19(11):1363-73. doi: 10.1039/ c7em00315c.

25. Canals L Mauricio, Canals C Andrea. Percolación de la epidemia de influenza AH1N1 en el mundo: Utilidad de los modelos predictivos basados en conectividad espacial. Rev Med. Chile. [Internet]. 2010 Mayo;138(5):573-80. doi: http://dx.doi.org/10.4067/ S0034-98872010000500007

26. Robert Koch Institute .COVID-19 in Germany. [Internet]. 2020 [cited Apr 22, 2020]. Available from: https://www.rki.de/DE/Content/InfAZ/N/Neuartiges_ Coronavirus/Fallzahlen.html

27. Infection au nouveau Coronavirus (SARSCoV-2), COVID-19, France et Monde. [Internet]. 2020 [cited May 5, 2020]. Available from: https://www. santepubliquefrance.fr/maladies-et-traumatismes/ maladies-et-infections-respiratoires/infection-acoronavirus/articles/infection-au-nouveau-coronavirussars-cov-2-covid-19-france-et-monde

28. Department of Health and Social Care and Public Health (England) Number of coronavirus (COVID-19) cases and risk in the UK. [Internet]. 2020 [cited May 5, 2020]. Available from: https://www.gov.uk/guidance/ coronavirus-covid-19-information-for-the-public

29. Federal Office of Public Health (Switzerland). New coronavirus. [Internet]. 2020 [cited May 5, 2020]. Available from: https://www.bag.admin.ch/bag/en/ home/krankheiten/ausbrueche-epidemien-pandemien/ aktuelle-ausbrueche-epidemien/novel-cov.html

30. Ministerio de Sanidad (España). Situación de COVID-19 en España. [Internet]. 2020 [Acceso mayo 2020]. Disponible en: https://covid19.isciii.es/ 
31. Ministério da Saúde (Portugal). Direção-Geral da Saúde. Disponibilização de Dados. [Internet]. 2020 [Acesso 5 mai 2020]. Disponível em: https://covid19. min-saude.pt/disponibilizacao-de-dados/

32. Ministero della Salute (Italia). Covid-19, i casi in Italia il 28 aprile ore 18. [Internet]. 2020 [cited May 5, 2020]. Available from: http://www.salute.gov.it/portale/ nuovocoronavirus/dettaglioNotizieNuovoCoronavirus. jsp?lingua $=$ italiano\&menu $=$ notizie $\& p=$ dalministero $\&$ id $=4632$

33. Directorate of Health (Iceland). COVID-19 in Iceland Statistics. [Internet]. 2020 [cited May 5, 2020]. Available from: https://www.covid.is/data

34. Republic of Austria. Federal Ministry Social Affairs, Health, Care and Consumer Protection. Official COVID-19 Dashboard - Explanatory Notes [Internet]. 2020 [cited May 5, 2020]. Available from: https://www. sozialministerium.at/en/Coronavirus/Official-COVID-19Dashboard---Explanatory-Notes.html

35. Rijksinstituut voor Volksgezondheid en Milieu. Current information about COVID-19 (novel coronavirus) [Internet]. 2020 [cited May 5, 2020]. Available from: https://www.rivm.nl/coronavirus-covid-19/actueel

36. Folkehelseinstituttet. Daily reports about coronavirus disease (COVID-19). [Internet]. 2020 [cited May 5, 2020]. Available from: https://www. fhi.no/sv/smittsomme-sykdommer/corona/dags--ogukerapporter/dags--og-ukerapporter-om-koronavirus/ 37. Folkhälsomyndigheten. Bekräftade fall i Sverige daglig uppdatering. [Internet]. 2020 [cited May 5, 2020]. Available from: https://www.folkhalsomyndigheten. se/smittskydd-beredskap/utbrott/aktuella-utbrott/ covid-19/bekraftade-fall-i-sverige

38. Sundhedsstyrelsen. COVID-19 update: statistics and charts. [Internet]. 2020 [cited May 5, 2020]. Available from: https://www.sst.dk/da/corona-eng/ COVID-19-update_-statistics-and-charts

39. Haniffa R, Isaam I, De Silva AP, Dondorp AM, De Keizer NF. Performance of critical care prognostic scoring systems in low and middle-income countries: a systematic review. Crit Care. 2018 Jan;22(1):18. doi: 10.1186/s13054-017-1930-8

40. Wild C, Narath M. Evaluating and planning ICUs: methods and approaches to differentiate between need and demand. Health Policy. 2005 Mar;71(3):289-301. doi: https://doi.org/10.1016/j.healthpol.2003.12.020

41. Sociedad Chilena de Medicina Intensiva. Encuesta diaria realidad nacional intensivo 05 de Mayo. [Internet]. 2020 [Acceso 5 mayo 2020]. Disponible en: https:// www.medicina-intensiva.cl/site/covid/img/noticias/ informe_02MAY2020.pdf

42. Ministerio de Ciencia, Tecnología, Conocimiento e Innovación (Chile). Datos COVID-19. [Internet]. 2020 [Acceso 5 mayo 2020]. Disponible en: http://www. minciencia.gob.cl/covid19

43. Canals L Mauricio. Predictibilidad a corto plazo del número de casos de la influenza pandémica AH1N1 basada en modelos determinísticos. Rev Chil Infectol. [Internet]. $2010 \mathrm{Abr} ; 27(2): 119-25$. doi: http://dx.doi. org/10.4067/S0716-10182010000200003. Creative Commons (CC BY).

This license lets others distribute, remix, tweak, and build upon your work, even commercially, as long as they credit you for the original creation. This is the most accommodating of licenses offered. Recommended for maximum dissemination and use of 